that we have not space to give extracts from the many charming accounts of the habits of our English birds of prey, which have certainly not been surpassed by any modern writer. We have already alluded to the anomalous position given to the Osprey in Mr.Seebohm's classification, and we notice that in the characters which he assigns to the genus (p. 54) he does not refer to the skeleton, which is so essentially Owl-like in structure. The author calls attention to a very serious slip made by ourselves in the "Catalogue of Birds" with regard to the Rough-legged Buzzard (Archibuteo lagopus). We were certainly in error in placing this bird with the genus Buteo, and indeed the woodcut of the reticulated tarsus convicts us on the face of it; but we strongly doubt the correctness of Mr. Seebohm's relegation of the species to the genus Aquila, and we hardly think that Dr. Gadow's evidence as to the resemblance of certain points in the anatomy of the genera Aquila and Archibuteo was intended to suggest that they were closely enough allied to be considered inseparable. On p. I 34 we are told that "ornithologists seem to have a fatality for making petty blunders." This probably accounts for Mr. Seebohm's admitting (p. I30) a woodcut of the nest of the Hen Harrier with the bird appearing in the background about the size of a Song Thrush. Perhaps Mr. Whymper, the artist who has drawn this otherwise pretty sketch, will, like Mr. Hanhart, who has done the plates of the eggs, "get better as he improves." (Vide the "Notice to Subscribers.")

Passing on to the family Strigida or Owls, we find with regret that $\mathrm{Mr}$. Seebohm has once more ruthlessly destroyed the simplicity of nomenclature in the European species, and this on the authority of the "Storia degli Uccelli," whose fourfold authorship would surely be more than sufficient to place the book out of court. The genus Aluco is once more invoked for the Barn Owl, Strix is restored to the Tawny $\mathrm{Owl}$ as well as to the Long-eared Owl, Short-eared Owl, and Tengmalm's Owl, and the Snowy Owl and the Hawk Owl are placed in one genus, Surnia. This classification of the Owls is by far the most disappointing portion of Mr. Seebohm's book, and ornithologists will be inclined to view with suspicion the ideas of an author who, in endeavouring to upset the rules of the British Association, requires them to pin their faith to a system which would lead to such a result as is here offered to us. Gerini's "Ornithologia Methodict Digesta" may have gone down a hundred and forty years ago, but in the present day it appears to be "Chaos, rudis indigestaque moles," which the stomachs of the present generation of ornithologists will not be found strong enough to assimilate. A little woodcut is appropriately inserted as a tailpiece on p. 182 , which represents the author coming to grief on a downhill path!

In the account of the Passerida, or Singing Birds, another suggestive tailpiece at once meets our eye at p. 199: it represents a peaceful scene on a river, and is probably placed there as emblematical of the joy of the author at finding himself once more in smooth waters. The rest of the volume is occupied with an account of the Thrushes and Warblers, Chats, Redstarts, and Flycatchers, with which birds Mr. Seebohm possesses an acquaintance beyond that of any of his contemporaries; and no one who reads his book will find fault with this portion of the work, which appears to us to be in every way excellent. We unhesitatingly express our opinion that since the time of Macgillivray no such original book as Mr. Seebohm's has been published on British ornithology, and, in spite of a few less satisfactory illustrations, we think that the figures of the eggs are by far the best that have yet been given. We have ourselves too often run counter to the rules of the British Association Com mittee to allow of a suspicion of our complete sympathy with these rules, and Mr. Seebohm has done much to prove their unworkable character in many instances, but at the same time his strong expressions with regard to some of their most conscientious supporters seem to us likely to lessen the respect with which many of his incontrovertible strictures would otherwise have been received.

Another most useful ornithological work has also just made its appearance in Mr. Eugene Oates's "Handbook to the Birds of British Burmah." I Although less ambitious in its scope than Mr. Seebohm's work above noticed, it is nevertheless a very complete résumé of the ornithology of the country of which it treats, and it forms one of those useful volumes which appear from time to time from the pens of bardworking ornithologists, which bring into one focus the results of many scattered essays in various journals. It must not be supposed, however, that Mr. Oates's work has been confined to the incorporation of the labours of his predecessors, for although he has gathered together into one compass the results of the travels of Mr. Davison and Capt. Bingham in Tenasserim, and of Capt. Wardlaw Ramsay in Karennee, the book is also enriched with an account of his own personal experiences during a fourteen years' residence in Pegu. One great characteristic of this book is its conciseness. In the present volume of 430 pages, four hundred species are disposed of, and yet the principal references are given, as well as descriptions of all the species. In fact, the book quite comes up to our idea of what a model "handbook" should be, and there is no doubt that it will be simply invaluable to the collector in British Burmab, within whose reach it is placed by the exceedingly modest price at which it is published. All workers in the field of Indian and Indo-Malayan ornithology will not be able to do without this most useful volume.

\section{R. BOWDLER SHARPE}

\section{THE AURORA BOREALIS ${ }^{2}$}

III.

THE "Utstromnings" Apparatus.-On the top of a mountain, or in a spot situated so high that it commands the surrounding country within a radius of some 5 kilometres, the apparatus, which I have termed an "utströmnings" apparatus, should be erected. This instrument consists of a copper wire, at least $2 \mathrm{~mm}$. in diameter, laid out on insulators fixed or poles 2 metres in height, along which points or nibs of copper or brass are attached at every half metre in such a way that they always point upwards. The wire is, I believe, arranged with most advantage as shown in the subjoined Fig. I. If the wire begins at $O$, and the distance $O^{\prime}$ is $=$ I 8 metres, the total surface area of the apparatus will be $=324$ square metres. The letter $i$ indicates insulator.

The length of the wire is, therefore, 194 metres, and the number of insulators, if one insulator is attached in the centre of each outer coil, $=27$.

The insulators should be of a peculiar construction, so that they would, under all conditions, even when covered by hoar frost, be perfectly efficient. The kind shown in Fig. 2, based on the principle of M. Mascart's insulator, appears to me to be the most serviceable.

This diagram shows the vertical section of the insulator attached to the pole. $a b$ is a glass tube $7 \mathrm{~mm}$. thick, $5 \mathrm{~cm}$. in diameter, and $20 \mathrm{~cm}$. in height. This tube is soldered to the bottom of the jar $c$ def, the outer diameter of which is $11 \mathrm{~cm}$., and height $13.5 \mathrm{~cm}$., and is, at the side, $10 \mathrm{~cm}$. from the bottom, provided with an opening o $(2 \mathrm{~cm}$. in diameter), which can be closed with a cork. Above the tube, $a b$, the bell, $m n n^{\prime}$ is affixed, which is provided with arms for the coiling of the wire. In the cork, $o$, a U-shaped glass retort, with short arms pointed downwards, is inserted, and if the retort fede is filled

x "A Handbook to the Birds of British Eurmah, including those found in the adjoining State of Karennee," by Eugene W. Oatts, Executive Engineer, Public Works Defartment of India (British Burmah). London R. H. Porter, 6, Tenderden Street, W., and Dulan and Co., $x \varepsilon_{3}$.

${ }^{2}$ Continued from p. Ic9. 
with sulphuric acid, the outer surface of the glass tube, $a b$, will be kept dry, and almost completely insulated. The distance between the jar and the bell should be as great as possible, in order that the hoar-frost may not form a bridge across the intervening space.

From this apparatus a telegraph wire is led on poles

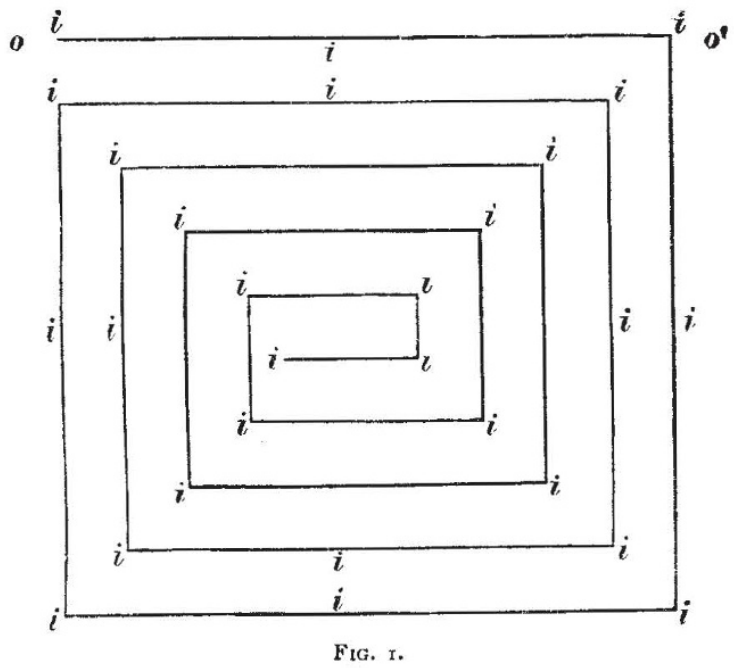

provided with insulators to a convenient chamber of observation. The conducting wire may, when the abovedescribed kind of insulators is used, be an ordinary iron wire $2 \mathrm{~mm}$. in diameter. The poles should be at most 40 metres apart.

The galvanometer should be constructed with a great

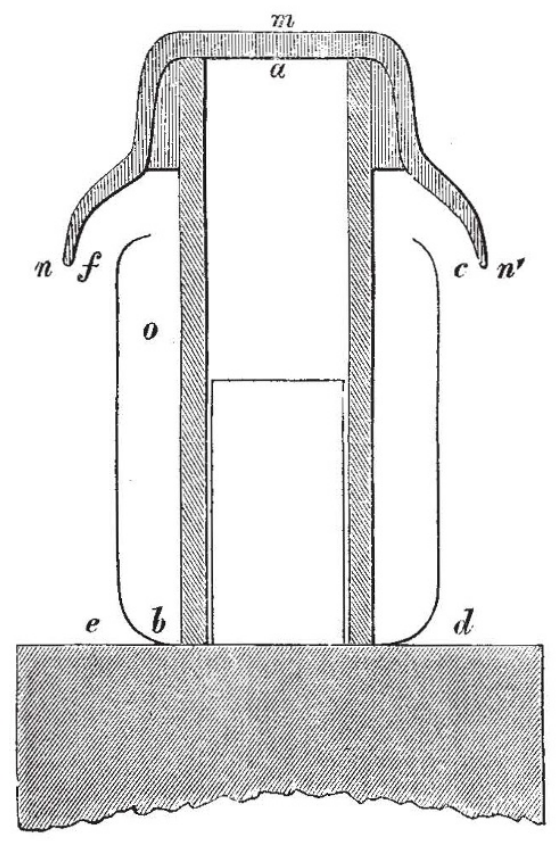

FIG. 2.

number (about 10,000) coils, and be provided with a pair of astatic needles, near which the mirror is affixed. In order to avoid too great oscillations, the needles should be hung side by side on fine threads of cocoon silk, the distance between the ends of the threads may be regulated according to circumstances. The readings should be made with a telescope and scale. It is besides clear that the conductive resistance of the galvanometer should be exactly measured, and that the readings of the instrument should be verifier, as, for instance, with an inductor whose action on the galvanometer has been ascertained in absolute measure. For this purpose an ordinary Daniell's element may serve, and may in fact be the best, as a similar element should also be used for the actual measurements. If an iron wire is used it must of course be replaced with one of copper near the chamber of observation. The earth conductor of the current is a zinc disk about 4 square decimetres in area. The theory of the apparatus is this:-The entire quantity of electricity which is suffused in a certain. part of the atmosphere which is situated above a certain horizontal plane, as that formed by the points in the "ütströmnings" apparatus, produces in each one of these points an electromotive force. And if the potential of these quantities of electricity on all the points be denominated as $V_{a}$, and the potential of the aggregate electricity on the zinc disk as $V_{z}$, the electromotive force $E$ will be-

$$
E=V_{a}-V_{z},
$$

and the strength of the current $i$

$$
i=k \frac{V_{a}-V_{z}}{R} \text {, }
$$

where $R$ denotes the whole conductive resistance, and $k$ a constant dependent on the construction of the galvanometer, \&c.

Generally, $V_{z}$ is assumed $=0$; but this is, in the present case, not correct ; we therefore put-

$$
i=k{ }_{R}^{E} \text {. }
$$

If a constant element is introduced into the current, we have, if the electromotive force is denominated $e$, and the internal resistance of the element is not taken into account-

$$
i_{1}=k \frac{e}{R},
$$

when $i_{1}$ means the intensity of the current which is created by the galvanic element.

If the positive pole is turned first against the "utströmnings " apparatus, we obtain-

$$
i-i_{1}=\delta \text {, }
$$

and if the negrative pole is turned against it-

$$
i+i_{1}=\delta^{\prime}
$$

i.e. if $\delta$ and $\delta^{\prime}$ means the deflexion of the galvanometer in each case.

We obtain therefore in $i$ a measure of $\frac{E}{R}$, and in $i_{1}$ a measure of $\frac{e}{R}$. If the deflexions are always reduced to the same value for $\frac{e}{R}$, which is easily done as $e$ is constant, we obtain measures capable of being compared with $E$ or $V_{a}-V_{z}$.

In the deflexions observed when a constant galvanic element is introduced into the circuit, one obtains, when the element is turned in the first instance with the positive pole against the "utströmnings" apparatus, and in the second against the earth-plate, a relative measure of the potential due to induction in the air on the particular occasion. From this it will appear that the observations should always be effected in the following manner:-

I. With the constant element in the current-

(a) With the positive pole against the apparatus.

(b) With the positive pole against the disk in the earth.

2. Without the element in the current-

(a) First deflexion.

(b) Constant deflexion. 
3. With the constant element in the current--

(a) With the positive pole against the apparatus.

(b) With the positive pole against the disk in the earth.

The deflexions obtained will give the particulars required for an easy calculation of the strength of the current from the atmosphere to the earth.

I am fully aware that several details of this method may be open to discussion, but I do not deem others than the following of any great importance, viz. that as the intensity of the current is greatly dependent on the condition of the points, a gradual oxidation of the same will have the effect of causing an alteration in the current. This alteration also takes place in the strength of the current from the c instant element, so that even the deflexions caused by the same will always be a measure of the aggregate potential due to induction, both through the points and in the air.

As it is not always possible to calculate the extent of the deflexions, an instrument permitting part of the current to be shunted should be employed. When the apparatus is erected care should be taken that the beight between the disk in the earth and the apparatus is at least I 80 metres; but experiments with disks at various elevations are of course of great interest.

From the account I have thus given of my experiments at Sodankylä, I think that all the subsidiary points which should be taken into account, as well as those questions which still await solution in connection with the aurora borealis, will be readily comprehended. It would, however, be of great advantage when making similar experiments to have two sets of apparatus; while thus measurements are being made with one, the variations in the current could be traced with the other, and thus the particulars requisite for a reduction to a fixed mean standard would be obtained.

$$
\text { SELIM LEMSTRÖM }
$$

Professor of the Helsingfors University

\section{HISTORICAL NOTES IN PHYSICS}

\section{I.-The Discovery of the Electric Light}

IN looking through an old volume of the Journal de Paris, I came across the following entry, for the date 22 Ventôse, An X. (March I2, 1802), which clearly relates to an exhibition of the electric arc light :-

"Le citoyen Robertson, auteur de la tantasmagorie, fait dans ce moment, des expériences intéressantes, et qui doivent sans doute avancer nos connoissances sur le galvanisme. Il vient de monter des piles métalliques, au nombre de 2500 plaques de zinc, et autant en cuivre rosette. Nous parlerons incessament de ses résultats, aussi que d'une expérience nouvelle qu'il a faite hier avec deux charbons ardens. Le premier étant placé à la base d'une colonne de 120 élémens de zinc et argent, et le second communiquant avec le sommet de la pile, ils ont donné, au moment de leur réunion, une étincelle brillante, d'une extrême blancheur, qui a été aperçue par toute la société. Le citoyen Robertson répétera cette expérience le $25 . "$

The individual who thus came before the public was named Etienne Gaspard Robertson, a name suggestive of Scotch descent. He was better known for his "Phantasmagoria," exhibited a few years later in London. Of this invention a notice appears earlier in the volume from which the above passage is taken; and in an earlier volume of the Fournal de Paris in the month "Fructidor, An viii.," there occurs a mention of some of his experiments on the couronne de tasses of Volta.

It is worthy of casual notice that in the number where Robertson's "Phantasmagoria" is advertised, the very next advertisement on the page is one of an exhibition to be given by Citoyen Martin at the Hôtel de Fermes, where- in as part of a "spectacle extraordinaire et amusant de physique," \&c., was to be shown "l'expérience du télégraphie plus rapide que la lumière, d'un effet extraordinaire et amusant."

The usual date given for the invention of the electric light by Sir Humphry Davy is 1809 ; but I was aware that earlier notices existed both in Cuthbertson's "Electricity" (1807) and other works. I was also under the impression that some earlier reference to the matter existed in Davy's own works. The finding of this notice in the Fournal de Paris induced me to consult the early volumes of the Philosophical Magazine and of Nicholson's Fournal.

In the Philosophical Magazine, vol. ix. p. 219, under the date February I, I80 I, the following passage occurs in a paper by $\mathrm{H}$. Moyes of Edinburgh, in which experiments with a voltaic pile or column are described :-

"When the above column was at the height of its strength its sparks were seen in the light of the day, even when taken with a piece of charcoal held in the hand."

In the fournal of the Royal Institution, vol. i. (1802), Davy describes (p. I06) some experiments on the spark yielded by the pile, and states: "When, instead of the metals, pieces of well-burned charcoal were employed, the spark was still larger and of a vivid whiteness." On p. 214 he describes and depicts an "apparatus for taking the galvano-electrical spark in fluids and aëriform substances." This apparatus consisted of a glass tube open at the top and having a tubulure at the side through which a wire tipped with charcoal was introduced, another wire, also tipped with charcoal, being cemented in a vertical position through the bottom.

But earlier than any of these is a letter printed at p. I 50 of Nicholson's Fournal for October, I80o. This letter is entitled "Additional Experiments in Galvanic Electricity, in a Letter to Mr. Nicholson." It is dated "Dowry Square, Hotwells, September 22, 1800," and is signed by Humphry Davy, who at that time was assistant to Dr. Beddoes at the old Philosophical Institution in Bristol. The letter begins thus :-

"SIR,-The earlier experimenters on animal electricity noticed the power of well-burned charcoal to conduct the common galvanic influence. I have found that this substance possesses the same properties as metallic bodies in producing the shock and spark,${ }^{1}$ when made a medium of communication between the ends of the galvanic pile of Signor Volta."

In none of these extracts, however, is anything said of the properties of the arc as a continuous luminous spark. These were made known in Davy's later researches. Yet the electric light attracted attention as we see before the special property of continuity was observed.

\section{II.-The Invention of the Telephone}

In the Journal of the Physical Society of Frankfort-onthe-Main for $1860-61$ (p. 57) may be found a memoir on telephony by the galvanic current, in which its writer says: "I have now succeeded in constructing an apparatus by means of which $I$ am in a position to reproduce the tones of divers instruments, and even to a certain degree the human voice." The inventor further says : "Since the length of the conducting wire may be extended for this purpose just as far as in direct telegraphy, I give to my instrument the name "telephone." "Towards the end of the memoir it is stated that until now it had not been possible to reproduce the tones of human speech with a distinctness sufficient to satisfy everybody: "The consonants are for the most part tolerably distinctly reproduced, but the vowels not yet to an equal degree." The author of the memoir in which these remarkable statements occur was Philipp Reis. The paper from which the preceding quotations have been taken contains many other points of interest, and in particular a com"Here Davy adds a footnote: "The spark is most vivid when the charcoal is hot." 